\title{
FAKE NEWS AS A CRITICAL INCIDENT IN JOURNALISM
}

\author{
By Edson C. Tandoc Jr., Joy Jenkins, and Stephanie Craft
}

This study examines how American newspapers made sense of the issue of fake news. By analysing newspaper editorials and considering the problem of fake news as a critical incident confronting journalism, this study found that news organizations in the US recognize fake news as a social problem while acknowledging the challenge in defining it. They generally considered fake news as a social media phenomenon thriving on political polarization driven by mostly ideological, but sometimes also financial, motivations. Therefore, they assigned blame for the rise of fake news to the current political environment, to technological platforms Google and Facebook, and to audiences.

Keywords: boundary work, critical incident, editorials, fake news, journalism, social media

Authors:

Edson C. Tandoc Jr.

Corresponding Author

Associate Professor

Wee Kim Wee School of Communication and Information

Nanyang Technological University Singapore

$+65-6790-6110$

edson@ntu.edu.sg

Joy Jenkins

Postdoctoral Research Fellow

Reuters Institute for the Study of Journalism

Oxford University

joy.jenkins@politics.ox.ac.uk

Stephanie Craft

Associate Professor

College of Media

University of Illinois at Urbana-Champaign

scraft@illinois.edu

\section{Introduction}

Facebook has become a major platform for news consumption, with a lot of users incidentally getting their news via the social media site (Reid, 2017). It is no surprise that many news organizations have become so active on Facebook, promoting their stories there and chasing likes, shares, and comments (Tandoc and Maitra, 2017). Thus, news

organizations anticipated drawing high levels of social media engagement during the 2016 US presidential elections. However, their work was overshadowed by alternative forms of content on Facebook in the final three months of the campaign (Silverman, 2016b). These forms of content that went viral looked a lot like news - but were actually fake.

News organizations are right to consider the rise of so-called "fake news" a serious issue: it not only has the potential to mislead large numbers of people, but also to draw audience views and engagement away from real news produced by legitimate news 
organizations. An analysis by news and entertainment site BuzzFeed found that in the last three months of the 2016 US presidential campaign, the 20 top-performing fake news stories about the election collectively generated more shares, reactions, and comments on Facebook than the 20 best-performing real election stories combined (Silverman, 2016b). The bestperforming fake news story - that Pope Francis supposedly endorsed the candidacy of Donald Trump - generated more than 960,000 shares, reactions, and comments on Facebook alone (Silverman, 2016b). This is certainly not good news for traditional news organizations still struggling to find ways to grow their audiences online to match their declining audience figures in their traditional platforms.

Not only must news organizations compete for audience engagement with fake news, but they also find themselves defending their ranks from being called sources of fake news by US President Donald Trump and his supporters (Holan, 2017). The political news site PolitiFact, which monitors how often President Trump mentions or tweets the term "fake news," says that the president uses the term "to describe news coverage that is unsympathetic to his administration and his performance, even when the news reports are accurate" (Holan, 2017). This brings more confusion to what fake news actually means. Furthermore, fake news poses various threats to journalism as fake news articles not only compete for audience attention but also potentially undermine journalism's credibility while keeping journalists busy in defending themselves from fake news accusations instead of spending time doing actual reporting.

This current study defines fake news as articles based on false information packaged to look like real news to deceive readers either for financial or ideological gain. Not only have mainstream news organizations reported about some negative consequences of fake news - such as when a man opened fire at a pizzeria in Washington, DC in December 2016 after believing a viral conspiracy fake story that identified the pizzeria as the site of an underground child sex ring allegedly run by then-presidential candidate Hillary Clinton (Lopez, 2016) - but many of them have also seen their content overshadowed by fake news articles in terms of reach or have been branded as a fake news provider. By considering fake news as a critical incident in journalism, one that forces the journalism community to reflect on its practices and protect its ranks, this study looks into how news organizations in the United States made sense of fake news as a social issue by examining newspaper editorials that addressed the issue of fake news.

\section{Literature Review}

\section{The Rise of Fake News}

The rise of social media has changed how people consume news. Social media sites facilitate easy and quick diffusion of news as users can quickly share information and news articles to their network of friends (Lee \& Ma, 2012). Facebook, for example, comes with a share function, and users can either share an article on their own page, or post it on a friend's page, or send it through private messaging either to a particular friend or to a group. Social media sites also allow users to post their own news, such as when they witness events first hand (Neumayer and Rossi, 2018). These processes operate outside the control of traditional journalists, who once had a monopoly on news production and distribution. A consequence of these shifts, however, is the breakdown of verification.

The term "fake news" is not new. Studies have used the term to refer to different types of content, including political satire (Baym, 2005), news parodies (Berkowitz and Schwartz, 2016), press releases (Farsetta and Price, 2006), political propaganda (Khaldarova and Pantti, 2016), and photo manipulation (Zubiaga and Ji, 2014). These different 
conceptualizations vary in two dimensions: intention to deceive and level of facticity (Tandoc et al., 2017a). For instance, while satire and parodies use some level of deception for the main purpose of humor, propaganda and manipulations often seek deception as the main goal. Satires mimic news broadcasts and mock the news but they still depend on facts; parodies rely on fictitious accounts for humor (Tandoc et al., 2017a).

The 2016 presidential elections in the US brought the term back into the limelight, as fabricated stories went viral on social media (Vargo et al., 2017). From a post claiming that Pope Francis had endorsed Donald Trump (Silverman, 2016a) to a post claiming that Hillary Clinton and her former campaign manager operated an underground child sex ring (Lopez, 2016), fake news came to refer to "viral posts based on fictitious accounts made to look like news reports" (Tandoc et al., 2017a: 138). A study on the impact of fake news on the presidential elections defined fake news as "news articles that are intentionally and verifiably false, and could mislead readers" (Allcott and Gentzkow, 2017: 213). It has also been defined as "a knowingly false headline and story [that] is written and published on a website that is designed to look like a real news site, and is spread via social media" (Rochlin, 2017: 388). These definitions characterize fake news as forms of disinformation marked by high levels of intention to deceive and low levels of facticity that approximate the look and feel of real news (e.g. Rochlin, 2017; Allcott and Gentzkow, 2017).

Two main motivations drive the production of fake news. The first motivation is financial. When outrageous headlines trick readers into clicking on a story or if they are drawn to a particular story and visit the page, their clicks are converted into advertising dollars (Allcott and Gentzkow, 2017). Such is the case for the teenagers in Macedonia who profited from publishing fabricated stories (Subramanian, 2017). The second motivation is ideological or political. Some fake news producers are intentionally muddying public discourse, or discrediting particular personalities, to push for the political or ideological agenda they support (Allcott and Gentzkow, 2017; Albright, 2016).

Social media sites have presented news organizations with many challenges and the relationship between technology platforms and news publishers has always been complicated (Rashidian et al., 2018). While platforms have provided another channel for publishers to disseminate their content, platforms have also taken audience attention away from traditional news sites. "Journalism has played a critical part in pushing for accountability into the practices of companies such as Facebook, Google, and Twitter, yet newsrooms are increasingly oriented toward understanding and leveraging platforms as part of finding a sustainable future" (Rashidian et al., 2018: , para. 1). Fake news is presenting yet another challenge in this already complex and tense relationship. Fake news spreads through information-sharing among users on social media, as users receive information, including news, from fellow users, such as their friends or family. Thus, social media provides a networked design conducive for "peer-to-peer propaganda," or when "ordinary people experience the propaganda posts as something shared by their own trusted friends, perhaps with comments or angry reactions, shaping their own opinions and assumptions" (Haigh et al., 2017: 8). Fake news also heavily relies on a web of social media and online bots that swarm the internet with fake content, thereby conferring these fabricated stories with a cloak of legitimacy (Albright, 2016; Shao et al., 2017). So when some users countercheck by verifying fake information through a simple Google search, they will just end up finding the same fake story reported elsewhere (Tandoc et al., 2017b; Shao et al., 2017).

Fake news and the impact of disinformation on public opinion have become a source of concern for governments in many countries, with some nations discussing legislative interventions (CNA, 2017; Scott and Eddy, 2017). Similarly, scholars have begun understanding the larger social ramifications of fake news, such as in the legal context (Klein and Wueller, 2017) as well as in terms of affecting the news agenda (Vargo et al., 2017). 
What concerns many scholars is the impact of fake news on public opinion, with members of the public plausibly making decisions based on erroneous information (Tandoc et al., 2017b), such as during elections (Allcott and Gentzkow, 2017).

\section{Fake News as a Critical Incident}

While scholars refer to contemporary fake news in similar ways, politicians and others have also invoked "fake news" to indict journalists and news organizations when they deem their coverage false, biased, or misleading. This rhetoric has become so widely used that editorials and commentaries have emerged to counter fake news allegations and reinforce the tenets and democratic importance of journalism and journalists. These responses suggest that the use of "fake news" in political discourse constitutes a critical incident (Gerbner, 1973; Zelizer, 1992) for the journalistic field. A critical incident refers to an event or development that leads journalists to reconsider "the hows and whys of journalistic practice" (Zelizer, 1992: 67). These events function as discursive opportunities for journalists to ensure the well-being of their interpretive community by reconsidering, rearticulating, and reinforcing their boundaries and authority. Critical incidents are often shaped by two key elements: technology, or the devices through which events become news, and archetypal figures (Zelizer, 1992). Critical incidents are notable not only for their significance to the public but also for their significance to journalism and the journalists who use them to constitute their professional collective memory (Gilewicz, 2014).

Critical incidents are important for interpretive communities such as journalism, as they force communities to reflect on their practices and values (Zelizer, 1993). An interpretive community is defined as "a cultural site where meanings are constructed, shared, and reconstructed by members of social groups in the course of everyday life" (Berkowitz and TerKeurst, 1999: 125). As an interpretive community, journalistic work takes on a highly discursive nature, so that critical incidents are also reflected on discursively. The Watergate scandal, the Kennedy assassination, and the Vietnam War functioned as critical incidents for journalists (Zelizer, 1992). In particular, journalists used the Kennedy assassination to grapple with the rise of television news and question its legitimacy (Zelizer, 1990). Meltzer and Martik (2017: 215) summed up perspectives on critical incidents, noting that scholars consider these practices of self-reflection a "kind of ritual sacrifice, performed to persuade audiences to have faith in journalism, to sustain ratings and readership, and to deflect potential external criticism."

This process of self-reflection by journalism's interpretive community usually unfolds through journalistic works. For example, Parameswaran (2006) examined the September 11 terror attack in the US as a critical incident where the industry press used remembrances of the challenges journalists faced in reporting the story to frame journalists as heroes who continued their work even in the midst of chaos. The incident also revealed hierarchies in different types of news media largely favoring print and addressed journalists' shortcomings, such as lack of questioning of government agendas (Parameswaran, 2006). In making sense of Princess Diana's death in August 1997, mainstream news organizations distanced themselves from the paparazzi, who were blamed for the accident, through their articles and editorials that reaffirmed the boundaries of professional journalism and located the paparazzi outside these boundaries (Bishop, 1999). Of particular relevance to "fake news" debates, Feldman (2007) examined the rise of satire program "The Daily Show" as a critical incident that prompted journalists to reconsider their profession by focusing on the blurred lines between news and entertainment, the need to appeal to younger audiences, and the limitations of objectivity as a norm when considering how to best engage audiences. In these examples of critical incidents, journalists addressed shortcomings or confronted problems by 
highlighting their cherished norms and values as well as reaffirming the boundaries that set them apart from practices they consider unacceptable or potentially threatening or damaging to mainstream journalism.

The ongoing discourse around fake news also represents a critical incident through which journalists, as members of an interpretive community, responded to critiques of and attacks on their field to reinforce their legitimacy, especially in a period when journalism's boundaries are being challenged (Carlson and Lewis, 2015). Thus, research on boundary work is also a useful framework in analysing how journalists respond to critical incidents in journalism. When confronted by a critical incident, journalists often reflect on their values and norms by reasserting the normative boundaries of their profession and locating practices and actors that fall short of journalistic ideals as outside the boundaries of legitimate journalism (Berkowitz and TerKeurst, 1999; Bishop, 1999; Tandoc and Jenkins, 2016). Boundary work conceives of journalism as a territory whose boundaries must be constantly maintained (e.g. Carlson and Lewis, 2015). That maintenance often takes a discursive form, such as by calling attention to ways in which outsiders fail to meet journalistic standards or do not share journalism's values or ethics. For example, research has identified journalistic boundary work undertaken with regard to amateurs (Tong, 2015), audiences (Robinson, 2010), sources (Coddington, 2012) and new digital-native outlets such as BuzzFeed and Gawker (Tandoc and Jenkins, 2016; Tandoc and Jenkins, 2017).

A way to understand how a critical incident mobilizes journalists to reassert journalism's boundaries is to examine journalistic outputs as a form of discourse (Thomas and Finneman, 2014). Journalistic outputs offer a window not only into how journalists negotiate questions about their values and practices but also, importantly, how journalists present and characterize those values and practices for public consumption. For example, McDevitt and Ferrucci (2017) found a telling contrast between the discourse produced by journalists and by scholars in evaluating journalism's performance during the 2016 US presidential elections. While scholars considered Trump's rise as predictable, in part enabled by journalism's long-established practices and norms, journalists attributed Trump's win to fake news on social media and media illiteracy in the US (McDevitt and Ferrucci, 2017). What this shows is that while other sectors attributed Trump's win to journalistic coverage of the campaign - with the news media consistently responsive to what others dismissed as Trump's media antics - many journalists laid the blame to forces outside the boundaries of journalism (McDevitt and Ferrucci, 2017). This is characteristic of how journalism usually responds to scandals within journalism: affirming journalism's important role in democracy without taking any responsibility (Thomas and Finneman, 2014). Such a response has been argued to be "indicative of an institutional ideology that is quick to assert rights but largely resistant to notions of attendant responsibilities" (Thomas and Finneman, 2014: 172). This current study seeks to test this assumed institutional ideology by looking at how newspapers in the US characterized the rise of fake news.

Guided by the framework of boundary work, this study considers the problem of "fake news" as a critical incident in journalism. By examining newspaper editorials published about fake news, this study seeks to answer this specific question: How did news organizations in the US make sense of fake news as an issue?

\section{Method}

This study is based on a qualitative analysis of newspaper editorials about "fake news" published in the US. We focused on analysing discourse based on newspaper editorials because they represent a news organization's "official view" (Ryan, 2004: 366) and occupy "an important role in shaping public opinion" (Bonyadi, 2010: 324). Thus, they are also 
particularly important in understanding "the ideological role of news media" (Izadi and Saghaye-Biria, 2007: 140). Newspapers publish one editorial per issue, focusing on what their respective news organizations consider as the important topic of the day that merits a unified stance. While circulation figures for most newspapers in the US are consistently shrinking, some of them have retained their influence over the agenda of other media, a case of intermedia agenda-setting (Denham, 2014). We also included not only national but also local newspapers as surveys suggest that local newspapers remain influential among local readers (Meo, 2017).

We used the online database LexisNexis, which indexes articles published by news organizations. We limited our search to newspapers published in the US and used the search terms "fake news" and "editorials." We also excluded school publications. The search yielded 1,114 articles. Next, we excluded letters to the editor and opinion columns to focus only on editorials that represent the stand of the news organization. Finally, we excluded articles that were published before 2016, as we wanted to focus on discourse around fake news triggered by the US presidential elections in 2016. This resulted in the exclusion of 21 articles published between 1998 and 2015, which used fake news to refer to the news parody site The Onion or news satire programs such as The Daily Show. Following these steps left the study with 195 editorials for analysis, published between September 26, 2016 and September 1, 2017. The sample included editorials from 27 publications, ranging from national publications (i.e. Washington Post, The New York Times, The Los Angeles Times, and USA Today) to regional and local newspapers (e.g. St. Louis Post-Dispatch, Telegraph Herald, and Tampa Bay Times). Two publications were in tabloid format (i.e. The Journal Record and The New York Post) while the rest were broadsheets (see Table 1).

We used a constant comparative approach to data analysis, an analytical strategy originally developed for grounded theory but has been employed in other qualitative studies (Glaser, 1965; Glaser and Strauss, 1967). This approach provides two stages of analysis. The first stage, called open-coding, involves line-by-line coding, where each line in the data is coded by comparing it with the previous line and the previous code. This allowed a constant refining of codes. Three researchers engaged in individual coding by independently assessing the whole corpus of data. The second stage involves grouping the codes into related conceptual bins, also referred to as axial-coding (Glaser, 1965). This was also done by each of the three researchers. Following this, the three researchers then engaged in a discussion, where they compared, debated, and refined their individual categories to form three main themes. These larger themes were compared with the codes and categories that emerged from the earlier stages to ensure they were sufficiently grounded in the data. Finally, the researchers wrote narratives around each theme, which are discussed in the next section.

\section{Results}

Three main themes mark the journalistic discourse around fake news based on the newspaper editorials analysed for this study. First, newspapers in the United States clearly recognized fake news as an important issue and, by making it a subject of their editorials, legitimized it as a social problem. Second, newspapers problematized what fake news actually means and acknowledged the ambiguity of the term. Finally, the newspapers discussed responsibility for the spread of fake news. By identifying the political environment, technological platforms, and the news audience as responsible for the rise of fake news, they also reinforced journalism's boundaries by locating solutions outside the field.

Fake News as a Social Problem 
The editorial is a sacred - and precious - space in a newspaper. Not only does it represent the news organization's official stance on particular issues, but it is also a space reserved for what the news organization considers to be the most important issue that needs to be tackled. Thus, while a newspaper often contains multiple news stories, it publishes only one editorial per day (or issue). In devoting this space to fake news, newspaper organizations legitimized fake news a social problem.

Such recognition can be seen in how the newspapers described fake news. In an editorial published on 18 June 2017, The New York Times described it as "a global threat." Tampa Bay Times also wrote on 28 November 2016 that fake news "is quickly becoming a scourge on informed citizenship." The St. Louis Post-Dispatch also recognized that fake news plagues both political spectrums. In an editorial published on 6 December 2016, it said: "Fake news is an equal-opportunity menace. Liberals and conservatives alike are misled by it, and people on both sides have distributed it."

Some editorials also addressed the use of fake news, mainly by President Donald Trump, to discredit the press. The Vallejo Times-Herald, for example, wrote on 18 April 2017 that "facts that contradict Trump's version of reality are dismissed as 'fake news." These editorials considered this weaponization of fake news against the news media as an equally important problem with significant repercussions. For example, the Washington Post wrote on 8 March 2017:

When President Trump called the U.S. news media "the enemy of the American People" and brandished the moniker "fake news" at reports he didn't like, tyrants everywhere perked up. They heard the president say exactly what they have been saying about nettlesome journalists who expose human rights abuses, corruption and rigged elections. Mr. Trump's remarks have a ripple effect overseas, signaling that the United States will no longer champion freedom of the press and expression. This will inevitably lead to more repression.

Legitimizing fake news as a social problem also came with positioning journalism as a legitimate source of real news. This is consistent with journalists reinforcing the boundaries of journalism, distinguishing themselves from that which they do not consider as legitimate players. For example, Sentinel \& Enterprise wrote on 6 March 2017, in response to President Trump branding the news media as enemies:

The journalists who work long hours, nights, weekends and holidays - they are not the enemies of the people. The true enemies are those who would limit publication only to the world as they wish it to be, not to the world as it is.

This strategy of reminding readers of the boundaries of the field was particularly salient in the St. Louis Post-Dispatch's editorial on 12 January 2017. The editorial referred to President Trump getting a dose of his own medicine after he became the subject of what was then believed to be a series of leaks from a former British intelligence agent. Many news organizations did not publish the unverified accusations. But BuzzFeed did, even uploading some of the unverified documents. However, the Dispatch said: "That's not how reputable news organizations operate. Our code of ethics requires corroboration from two independent sources. We don't report rumors and innuendo." In an earlier editorial published on 6 December 2016, the Dispatch also admitted that news organizations get the news wrong once in a while. However, unlike fake news providers, journalists correct their mistakes. It said: 
Professional journalists get things wrong, but rarely intentionally. Reputable news organizations promptly run corrections when errors are found. Multiple layers of editors help ensure that personal biases are filtered out of news reports. The professional journalist's goal is to present only the facts to news consumers. It's a firing offense for any professional journalist to intentionally falsify news.

\section{Defining Fake News}

Using the term. The editorials referred to "fake news" in the same way they might reference other two-word terms such as "climate change" or "gun rights." That those things exist and can be editorialized about did not seem to be in doubt. However, the discourse we examined also included ways of referring to fake news that point to controversy over its definition and journalistic attempts to distinguish boundaries between fake news and "real" news.

References to fake news frequently appeared in quotation marks. Sometimes, this use of quotation marks followed the convention of indicating a verbatim statement by a person, as in a USA Today editorial on 12 July 2017 that said: 'President Trump repeatedly wrote off Russian interference as "fake news" and a Democratic Party myth to explain its election loss.' However, the use of quotation marks as "scare" or "sneer" quotes was also widespread in the texts, perhaps reflecting the purpose of editorials to criticize and raise questions about issues in the news. Scare or sneer quotes can be used to highlight or emphasize a term; to express the sarcastic or humorous attitude of the writer toward the words; to signal slang or jargon; or even to provide a way for the writer to distance herself from something dubious (Finnegan, 2011). All of these purposes were apparent in the editorials we examined, suggesting the contested nature of the very notion of "fake news" as something lacking a clear definition.

The ambiguity of fake news is evident in an editorial published by Pittsburgh PostGazette on 15 April 2017 that used scare quotes on the first reference to fake news, but dropped them on the second reference, treating the term as slang and indicating a lack of consensus about its definition:

After initially disputing the role that "fake news" played in the 2016 election, $\mathrm{Mr}$. Zuckerberg reversed himself and pledged to redouble his company's efforts to flag and eliminate fake news on its platform.

In a few cases, fake news was capitalized, mirroring a common way President Trump refers to Fake News in his tweets. Indeed, the news organizations' editorials that employed capitalization (or combined capitalization and quotation marks) appeared sympathetic to Trump. Even so, capitalization could, arguably, also be seen as a way to mock those tweets or even suggest "Fake News" is somehow the proper name of a character in a dramatic script. Telegram \& Gazette's editorial on 18 August 2017 illustrates this ambiguity:

Instead of lashing out at the "Fake News" for not giving him enough credit and calling out many in the media as "bad people," Mr. Trump should examine why this environment is what it is.

Given President Trump's frequent references to the media as "fake news," it is not surprising that some editorials picked up on this use of "fake news" as an adjective to describe the media. Thus, "fake news" also was employed as an adjective for terms such as "trend," "information," or, as in this example, "disinformation:" 
Investigators believe that as Election Day approached, Russian trolls and "bots" flooded the social media accounts of key voters in swing states with "fake news" disinformation about Clinton. (The State Journal-Register, 14 July 2017)

The contested nature of fake news was also underscored by the use of modifiers such as "so-called" and "alleged" in references to it. In conventional usage, "alleged" suggests that something may eventually be proved correct or true, but that does not seem to be the sense in which the adjective was used in the editorials. Rather, "alleged" indicates what the writer perceives as a phony contention that a piece of news is fake. In other words, these adjectives point to the artificiality, or fakeness, of fake news. For example:

Jeers to the people behind the alleged "fake news" story designed to take away public attention from accusations of Russian interference in last fall's election. (The Pantagraph, 4 August 2017)

The use of "so-called," on the other hand, seems more clearly aimed at communicating sarcasm and undermining the notion that "fake news" refers to a real thing. For example, The Lebanon Daily News wrote on 7 February 2017: "The controversy over socalled 'fake news' does not seem to be going away." In contrast, The Washington Post editorial on 22 August 2017 used "actual" as a modifier for "fake news" to support the idea that fake news exists:

[T]he president and the former sheriff... were ardent "birthers" who questioned whether Barack Obama was born in the United States, a touchstone of actual "fake news."

To say that birtherism represents actual fake news suggests not only that the Post editorial writer has a working definition of "fake news" but also that any alleged fake news could ultimately be evaluated according to that definition.

Contextualizing the term. Despite these different uses of the term, only a few editorials attempted to explicitly define fake news, and overall the journalistic discourse that emerged from the analysis mainly focused on differentiating fake news from what the journalists perceived as legitimate journalism. For example, the Monterey County Herald wrote on 2 December 2016 that fake news referred to "hoaxes and tin-hat conspiracy theories disguised as news." Such attempt at boundary work was carried out by discussing motivations for creating and spreading fake news; linking fake news to technology, thereby presenting it as a technological issue; and discussing fake news as a political phenomenon.

First, the editorials identified two main motivations for fake news: ideological and financial. Descriptions of ideological influence focused on fake news originating from Russia. In an editorial published on 2 August 2017, Telegram \& Gazette called Russian interference in the elections a "fake news campaign." These editorials suggested that fake news articles were designed to influence the election by damaging Hillary Clinton's reputation and reinforcing support for Donald Trump. Other editorials also highlighted the monetary motivation for fake news by referring to clickbait articles inserted into social media news feeds that not only sought to sway political beliefs but also to attract clicks. Tampa Bay Times wrote on 28 November 2016 that fake news providers "will never stop as long as advertising revenue keeps flowing." 
Second, the editorials addressed the involvement of social media platforms, particularly Google and Facebook. The New York Times wrote on 18 February 2017 that Facebook and Google were "widely criticized for their role in the spread of fake news during the American presidential campaign." The Daily News wrote on 18 November 2016 that Facebook was responsible for fake news, noting that "the dominant social network's computer code doesn't filter out articles from websites presenting outright falsehood as fact." Third, many editorials categorized fake news as a political phenomenon, born out of partisanship. The Santa Fe New Mexican argued on 3 January 2017 that fake news is related to political propaganda, as it is "purposely false, intended to deceive readers and viewers by playing with their belief systems - sometimes by reinforcing stereotypes and at other times by compelling them to lose confidence in former assumptions." Others distinguished between fake stories posted on websites designed to look like news sites and "political claims, which often have a basis in truth but exaggerate some part of the facts or give one person too much credit or blame" (Tampa Bay Times, November 28, 2016). The editorials also included references to the perceived liberal bias of the media, with a few editorials suggesting that any news stories emanating from these outlets, like The New York Times, CNN, the Associated Press, the Washington Post, and others, were biased and therefore fake news. For example, the Telegram \& Gazette wrote on 1 July 2017: "The Fake News Media have been feeding us so much garbage about Trump for so long, the American people don't know what or who to believe." Other editorials positioned fake news as a political strategy, most notably for Trump and Republican politicians, although they also referenced examples when Clinton and Democratic politicians referenced the claims of fake news by their opponents and suggested their losses were due to fake news.

Overall, many editorials recognized the challenge in, and debates about, defining fake news. The Daily Camera wrote on 19 November 2016 that: "In some cases, one person's fake news will be another person's strong opinion." Others recognized how loosely-and thereby confusing - the use of the term has become. For example, Telegraph Herald wrote on 4 August 2017: "Lately, all sorts of information is being dumped into the cauldron of "fake news." The Spokesman Review also wrote on 1 January 2017 that fake news "is being spun to mean any scrap of information someone doesn't like."

\section{Assigning Responsibility}

Linked to these efforts to define fake news, the editorials also discussed factors that facilitated its spread. In doing so, the news organizations engaged in assigning responsibility for this social problem. Specifically, they assigned blame to the political environment, technological platforms such as Facebook and Google, and the audience. In contrast, many newspapers wrote that journalists have to keep on doing what they have been doing - being ethical and responsible providers of real news - to fight fake news.

Political environment. Many of the editorials singled out Russia as the force behind many of the fake news stories that went viral during the campaign, echoing accusations that Russia used fake news to interfere in the national elections. For example, The New York Times wrote on 18 June 2017:

The Russians have engaged in behavior like this in other countries, and they're getting better at it. An American presidential election may be their biggest target to date, but it's hardly their first... They have disseminated fake news stories and other disinformation to interfere with elections in other countries, as they did here. 
Other editorials referred to the political polarization in the US as the context that allowed the spread of fake news, highlighting the role of ideology. Such polarization, coupled with changes in news consumption behaviors, provided an environment that was easy for external forces to exploit. For example, Telegram \& Gazette wrote on 25 April 2017:

At the seedy crossroads of political polarization and declining trust in media is where fake news loiters. Without a belief in professional, vetted, reliable sources of truth, truth may be determined by loyalty to an ideological team.

Technological platforms. Many editorials also referred specifically to Facebook and Google when assigning responsibility for fake news. For example, Tampa Bay Times wrote on 28 November 2016 that "platforms such as Facebook and Google that enable bogus stories to gain traction bear some responsibility." Many newspapers singled out Facebook, recognizing its increasingly important role in news consumption mainly because of its massive reach. Telegram \& Gazette wrote on 12 June 2017 that: "Facebook has created a Frankenstein monster with nearly 2 billion monthly active users." Others questioned the technology platforms' refusal to be considered as media companies, arguing that it controls users' exposure to news without taking on the responsibility of gatekeeping. The Washington Post wrote on 19 November 2016 that "social media services must adjust to the reality that they now are news media outlets to some extent." Some editorials also wrote about Facebook's initiatives to address the problem of fake news - such as the plan to get independent, third-party fact-checkers to verify posts that are flagged by users as fake- but they expressed doubt whether such efforts would be effective. For example, The New York Post wrote on 19 December 2016:

With the left obsessed with the idea that "fake news" helped Donald Trump win the presidency, Facebook is promising a cure that could prove worse than the disease... Real fact-checkers are an extremely valuable resource-Snopes.com, in particular. But empowering any central board of authorities misses the real, pro-free-speech solution: The answer to "bad" speech, whether it's lies or hate, is more speech to counter it.

Audiences. Some editorials focused on the responsibility of news audiences. For example, The New York Post wrote on 22 June 2017 that "fake news mainly feeds people's existing prejudices." Many editorials said audiences should be critical of what they read. Some of the editorials that highlighted the role of technology linked this with how audiences use these platforms. Several editorials referenced audiences just staying within their ideological silos or filter bubbles on social media. For example, Tampa Bay Times wrote on 28 November 2016:

(The) onus remains with news consumers to vet what they read. That may require venturing outside the information bubble many readers have created around themselves by choosing partisan stories that validate their political positions, which are then replicated in their digital newsfeeds.

Some newspapers included specific steps that audiences should take to ascertain that what they read is real. In an editorial published on 3 January 2017, the Santa Fe New Mexican asked readers to refer to available lists of fake news sites, read the "about" sections of dubious sites, and compare articles from "reputable news sites" with those posted on Facebook. The Christian Science Monitor, in an editorial published on 1 December 2016, 
called for schools to teach online media literacy and for parents to guide their children. The Los Angeles Times also wrote on 4 April 2017:

Good citizens test assumptions, question leaders, argue details, research claims. Investigate. Read. Write. Listen. Speak. Think. Be wary of those who disparage the investigators, the readers, the writers, the listeners, the speakers and the thinkers. Be suspicious of those who confuse reality with reality $\mathrm{TV}$, and those who repeat falsehoods while insisting, against all evidence, that they are true. To defend freedom, demand fact.

Journalists. Some of the editorials also recognized that, considering the threat of fake news, journalists must do their part. In announcing that it has joined a partnership among local media organizations to develop a unified stance against fake news, Sentinel \& Enterprise wrote on 30 January 2017:

The phenomenon of "fake news" demands a serious response from news consumers, from newsmakers and, not least, from the legitimate news media. We in the local news media are committed to doing our part.

But what is this part, specifically, that journalists have to play? The editorials that reflected on the role of journalists, to a large extent, reaffirmed existing journalistic norms and values - a set of rules and principles that have existed even before the rise of fake news. For example, Telegram \& Gazette wrote on 25 April 2017:

What is the answer? It is obviously complicated to rebuild ties of institutional trust and individual empathy. But one response must be: a journalism of rebuilt standing. A journalism that enforces the highest standards of accuracy and professional conduct. A journalism that refuses the temptation to join the ideological battle as a combatant.

Such discourse references valued journalistic norms, such as accuracy and fairness, as if the editorials are talking to other journalists. However, these are affirmations of what journalism has long been idealized to be. This can also be observed in how a few editorials cautioned against any form of censorship to curb fake news, since news organizations themselves benefit from press freedom. For example, in an editorial published on 1 December 2016, The Christian Science Monitor wrote:

Censoring news or appointing some arbiter to declare what is truthful won't work and endangers the rights of citizens to a "free press."

\section{Discussion}

This study examined newspaper editorials to understand how news organizations in the US made sense of the rise of fake news. Not only does fake news threaten public discourse, with public opinion potentially influenced by inaccurate information, but fake news also challenges actual journalism in engaging the public in a period when many news organizations are struggling to grow their audience numbers online. Fake news is also being used by politicians around the world to discredit news organizations that publish negative reports about them. By considering fake news as a critical incident in journalism, this study examined how and where traditional news organizations located the boundaries between fake and real news. The discourses reflect key elements that tend to shape critical incidents, such 
as the emergence of a new technological tool that shapes news distribution-in this case social media - and archetypal figures - in this case politicians and fake news providers interacting with the journalistic field (Zelizer, 1992).

News organizations clearly recognize fake news as a social problem, tackling it as an issue in their editorials, a space imbued with institutional significance often reserved for addressing important social issues. They also acknowledged the challenge in defining fake news. They considered fake news as a social media phenomenon that breeds on political polarization driven by mostly ideological, but sometimes also financial, motivations. Therefore, they assigned blame for the rise of fake news to the current political environment, to technological platforms Google and Facebook, and to audiences. Although news organizations also admitted they also have to do their part, this was limited to playing by the same set of rules that have long been prescribed for responsible journalism.

The editorials we analysed suggested that fake news is a new problem, when it has long existed under different terminologies, such as propaganda. What characterizes fake news in the current milieu is how it is facilitated by social media. Fabricated stories have spread before, but now they spread much faster not only because of social media's technological affordances, but also because of how users have domesticated social media in their daily lives. Information sources are conflated on social media and users often trust information they receive from other users they personally know (Kang et al., 2011). On one hand, while news organizations treat fake news as a new problem, they seem to respond to it in old ways. This reflects their need to use critical incidents to constitute professional collective memory in a familiar way (Gilewicz, 2014). On the other hand, seeing fake news only as a novel byproduct of social media, instead of another hybrid of disinformation and propaganda that journalism has long confronted and navigated into, can also limit journalists' ability and willingness to effectively and proactively counter the problem.

The results of this study should be examined in the context of several limitations. First, while newspaper editorials show what journalists consider as the most important issues of the day, discourse around fake news also occur in other forms of journalistic texts that future studies should also consider, such as news articles. Second, an editorial represents a news organization's official stance, but individual journalists also engage in reflections about their norms and practices. Future studies should also consider these other forms of discourse. Finally, as fake news spreads outside the US, future studies should also explore journalistic discourses around fake news in other media contexts. Still, despite these limitations, this study hopes to contribute to ongoing investigations and reflections about the important - and real-implications of fake news.

The epistemology of news has always focused on truth. Journalists have long valued the importance of accuracy and fairness in their work (Kovach and Rosenstiel, 2007). Discourse where the interpretive community merely reaffirms the same values it was supposed to value at all times seems incongruent to addressing what is treated, at least discursively, as a new problem. It also appears to reinforce narratives that "shed the best possible light on their tellers" and reinforce journalists' perspectives (Zelizer, 1990: 373). In a period when journalists seem to cling to technological innovations to survive economic uncertainty but also blame these platforms for journalism's newfound woes (Rashidian et al., 2018), many journalistic norms are at risk of being taken for granted. Speed is prioritized over accuracy (Bruno, 2011). Audience wants are prioritized over audience needs (Tandoc and Thomas, 2014). It seems that as they navigate a period of disruption, marked by a deluge of data and a cacophony of new technologies, journalists need to be reminded of what, at the very basic, journalism ought to be. The rise of fake news offers journalism an incident to remind itself and its audiences of what journalism should never be - and why real news should be sustained and protected. 
Journalism is founded on truth, regardless of whether it is favourable or not to any particular individual or group. Real news is based on facts so that public opinion and decision are not misguided. As fake news competes with real news for audience attention as well as for credibility, the journalistic field cannot always - and exclusively - blame external forces for its internal woes. Journalists should strive to maintain a fragile balance between preserving the journalistic field's autonomy and keeping up with how external forces and fields are quickly evolving. The institutional ideology marked by strong claims to social power while being resistant to accountability (Thomas and Finneman, 2014) is not sustainable - it serves neither the interest of journalism nor the public that it vows to serve.

\section{Acknowledgements}

The authors wish to thank Lim Wenliang Darren and Muhammad Syafiq Bin Muhammad Shahiddin who helped in finding, collecting, and sorting the sample of editorial articles for this study. They were undergraduate students at Nanyang Technological University Singapore (NTU) at the time of data collection and took part in the university's Undergraduate Research Experience on Campus (URECA) program. 


\section{References}

Albright J. (2016) The \#Election 2016 micro-propaganda machine. Medium. (accessed April 1, 2017).

Allcott H and Gentzkow M. (2017) Social media and fake news in the 2016 election. Journal of Economic Perspectives 31(2): 211-236.

Baym G. (2005) The Daily Show: Discursive integration and the reinvention of political journalism. Political Communication 22(3): 259-276.

Berkowitz D and Schwartz A. (2016) Miley, CNN and The Onion. Journalism Practice 10(1): 1 - 17.

Berkowitz D and TerKeurst JV. (1999) Community as interpretive community: rethinking the journalist-source relationship. Journal of Communication 49(3): 125-136.

Bishop R. (1999) From behind the walls: Boundary work by news organizations in their coverage of Princess Diana's death. Journal of Communication Inquiry 23(1): 90-112.

Bonyadi A. (2010) The rhetorical properties of the schematic structures of newspaper editorials: A comparative study of English and Persian editorials. Discourse \& Communication 4(4): 323-342.

Bruno N. (2011) Tweet first, verify later? How real-time information is changing the coverage of worldwide crisis events Reuters Institute for the Study of Journalism. (accessed October 5, 2017).

Carlson M and Lewis SC. (2015) Boundaries of journalism: Professionalism, practices, and participation. In: Zelizer B (ed) Shaping inquiry in culture, communication, and media. New York: Routledge.

CNA. (2017) Government 'seriously considering' how to deal with fake news: Shanmugam. Channel News Asia. (accessed April 10, 2017).

Coddington M. (2012) Defending a paradigm by patrolling a boundary: Two global newspapers' approach to WikiLeaks. Journalism \& Mass Communication Quarterly 89(3): 377-396.

Denham BE. (2014) Intermedia attribute agenda setting in the new york times: The case of animal abuse in U.S. Horse racing. Journalism \& Mass Communication Quarterly 91(1): 17-37.

Farsetta D and Price D. (2006) Fake TV news: Widespread and undisclosed (accessed April 6).

Feldman L. (2007) The news about comedy: Young audiences, The Daily Show, and evolving notions of journalism. Journalism 8(4): 406-427.

Finnegan R. (2011) Why do we quote? The culture and history of quotation, Cambridge, UK: Open Book Publishers.

Gilewicz N. (2014) To embody and to embalm: The uses of collective memory in the final editions of failed newspapers. Journalism 16(5): 672-687.

Glaser BG. (1965) The constant comparative method of qualitative analysis. Social Problems 12(4): 436-445.

Glaser BG and Strauss A. (1967) The discovery of grounded theory: Strategies for qualitative research, London: Weidenfeld and Nicolson.

Haigh M, Haigh T and Kozak NI. (2017) Stopping fake news: The work practices of peer-topeer counter propaganda. Journalism Studies: 1-26.

Holan A. (2017) The media's definition of fake news vs. Donald Trump's. PolitiFact. (accessed October 29, 2017).

Izadi F and Saghaye-Biria H. (2007) A Discourse Analysis of Elite American Newspaper Editorials: The Case of Iran's Nuclear Program. Journal of Communication Inquiry 31(2): 140-165. 
Kang H, Bae K, Zhang S, et al. (2011) Source cues in online news: Is the proximate source more powerful than distal sources? Journalism \& Mass Communication Quarterly 88(4): 719-736.

Khaldarova I and Pantti M. (2016) Fake news: The narrative battle over the Ukrainian conflict. Journalism Practice 10(7): 891-901.

Klein D and Wueller J. (2017) Fake news: A legal perspective. Journal of Internet Law 20(10): 1-13.

Kovach B and Rosenstiel T. (2007) The elements of journalism : what newspeople should know and the public should expect, New York: Three Rivers Press.

Lopez G. (2016) Pizzagate, the fake news conspiracy theory that led a gunman to DC's Comet Ping Pong, explained. Vox. (accessed March 17, 2017).

McDevitt M and Ferrucci P. (2017) Populism, journalism, and the limits of reflexivity. Journalism Studies: 1-15.

Meltzer K and Martik E. (2017) Journalists as communities of practice: Advancing a theoretical framework for understanding journalism. Journal of Communication Inquiry 41(3): 207-226.

Meo G. (2017) Research: Local newspapers still influence political opinion leaders. Media Research Blog. (accessed September 5, 2018).

Neumayer C and Rossi L. (2018) Images of protest in social media: Struggle over visibility and visual narratives. New Media \& Society: 1461444818770602.

Parameswaran R. (2006) Military metaphors, masculine modes, and critical commentary: Deconstructing journalists' inner tales of September 11. Journal of Communication Inquiry 30(1): 42-64.

Rashidian N, Brown P, Hansen E, et al. (2018) Friend and foe: The platform press at the heart of journalism. Columbia Journalism Review. (accessed July 11, 2018).

Reid D. (2017) US readers confuse Facebook for a news outlet. cnbc.com. (accessed October 29, 2017).

Robinson S. (2010) Traditionalists vs. convergers: Textual privilege, boundary work, and the journalist - audience relationship in the commenting policies of online news sites. Convergence: The International Journal of Research into New Media Technologies 16(1): 125-143.

Rochlin N. (2017) Fake news: Belief in post-truth. Library Hi Tech 35(3): 386-392.

Ryan M. (2004) Framing the War Against Terrorism: US Newspaper Editorials and Military Action in Afghanistan. Gazette (Leiden, Netherlands) 66(5): 363-382.

Scott M and Eddy M. (2017) Europe combats a new foe of political stability: Fake news. nytimes.com. (accessed March 31, 2017).

Shao C, Ciampaglia GL, Varol O, et al. (2017) The spread of fake news by social bots.

Silverman C. (2016a) Here are 50 of the biggest fake news hits on Facebook from 2016. BuzzFeed. (accessed March 4, 2017).

Silverman C. (2016b) This analysis shows how viral fake election news stories outperformed real news on Facebook. BuzzFeed. (accessed October 29, 2017).

Subramanian S. (2017) Inside the Macedonian fake-news complex. Wired. (accessed April 19).

Tandoc E and Jenkins J. (2016) Out of bounds? How Gawker's outing a married man fits into the boundaries of journalism. New Media \& Society 20(2): 581-598.

Tandoc E and Jenkins J. (2017) The Buzzfeedication of journalism? How traditional news organizations are talking about a new entrant to the journalistic field will surprise you! Journalism 18(4): 482-500.

Tandoc E, Lim ZW and Ling R. (2017a) Defining "fake news:" A typology of scholarly definitions. Digital Journalism 6(2): 137-153. 
Tandoc E, Ling R, Westlund O, et al. (2017b) Audiences' acts of authentication in the age of fake news: A conceptual framework. New Media \& Society: 1461444817731756.

Tandoc E and Maitra J. (2017) News organizations' use of Native Videos on Facebook:

Tweaking the journalistic field one algorithm change at a time. New Media \& Society Online First.

Tandoc E and Thomas RJ. (2014) The ethics of web analytics: Implications of using audience metrics in news construction. Digital Journalism 3(2): 243-258.

Thomas R and Finneman T. (2014) Who watches the watchdogs? Journalism Studies 15(2): 172-186.

Tong J. (2015) Chinese journalists' views of user-generated content producers and journalism: a case study of the boundary work of journalism. Asian Journal of Communication 25(6): 600-616.

Vargo C, Guo L and Amazeen M. (2017) The agenda-setting power of fake news: A big data analysis of the online media landscape from 2014 to 2016. New Media \& Society: 1461444817712086.

Zelizer B. (1990) Achieving journalistic authority through narrative. Critical Studies in Mass Communication 7(4): 366-376.

Zelizer B. (1992) CNN, the Gulf War, and journalistic practice. Journal of Communication 42(1): 66-81.

Zelizer B. (1993) Journalists as interpretive communities. Critical Studies in Mass Communication 10(3): 219-237.

Zubiaga A and Ji H. (2014) Tweet, but verify: epistemic study of information verification on Twitter. Social Network Analysis and Mining 4(1): 1-12. 
Table 1

List of Newspapers

Chicago Daily Herald

Chico Enterprise-Record (California)

Daily Camera (Boulder)

Investor's Business Daily

Monterey County Herald (California)

Sentinel \& Enterprise (Fitchburg,

Massachusetts)

Spokesman Review (Spokane)

St. Louis Post-Dispatch (Missouri)

Star News (Wilmington)

Tampa Bay Times

Telegram \& Gazette (Massachusetts)

Telegraph Herald (Dubuque)

The Christian Science Monitor

The Columbian (Vancouver)
The Daily News of Los Angeles

The Journal Record (Oklahoma)

The Lebanon Daily News

(Pennsylvania)

The New York Post

The New York Times

The Sante Fe New Mexican

The Washington Post

Vallejo Times-Herald (California)

USA Today

Pittsburgh Post-Gazette

The State Journal-Register

The Pantagraph

The Los Angeles Times 